DOI: 10.34015/2523-4552.2019.1.03

УдК 342.924

Сокальська О. В., кандидат юридичних наук, доцент, старший науковий співробітник науково-дослідного центру з питань діяльності органів та установ Державної кримінально-виконавчої служби України і пробації Інституту кримінально-виконавчої служби e-mail:co2001@ukr.net ORCID ID: 0000-0001-8737-0829

\title{
ГОЛОВНЕ ТЮРЕМНЕ УПРАВЛІННЯ РОСІЙСЬКОЇ ІМПЕРІЇ В ПОРТРЕТАХ ЙОГО ОЧІЛЬНИКІВ (ДО 140-ЛІТНЬОГО ЮВІЛЕЮ ВІДОМСТВА)
}

\footnotetext{
Усяка справа значною мірою залежить від особистості: з'явиться енергійна людина - і справа піде...

У статті окреслено передумови створення Головного тюремного управління Російської імперії, визначено його структуру та повноваження начальника управління. Уточнено перелік та хронологію перебування на посадах очільників Головного тюремного управління, їх біографічні дані, визначено та проаналізовано їх діяльність на чолі тюремного відомства.

Ключові слова: Головне тюремне управління Російської імперії; М. М. Галкін-Враський; А. М. Стремоухов; О. М. Максимовський; С. С. Хрульов; П. К. Гран; о. о. Жижиленко.

В статье определены предпосылки создания Главного тюремного управления Российской империи, его структура и полномочия начальника управления. Уточнен перечень и хронология пребывания на должностях руководителей Главного тюремного управления, их биографические данные, проанализирована их деятельность во главе тюремного ведомства.

Ключевые слова: Главное тюремное управление Российской империи; М. Н. Галкин-Враской; А. М. Стремоухов; А. М. Максимовский; С. С. Хрулев; П. К. Гран; А. А. Жижиленко.

Постановка проблеми. Однією зі складових формування цілісного образу в'язничної служби є історичний шлях її розвитку й діяльність очільників, а також їх об'єктивна оцінка. Саме до історії повсякчас апелюють можновладці та громадськість, обгрунтовуючи необхідність кардинальних змін в системі виконання покарань, але жодного разу - у 
позитивному сенсі. Їх основна теза: «усе, що було до нас - похмурі царські застінки і страхіття ГУЛАГу». Як не дивно, але саме таку риторику використовували й радянські (чи то пак «совєтські») ідеологи та науковці, лаючи на всі заставки ганебну «царську тюрму». Невтішно, що і молоді вітчизняні активісти пенітенціарної реформи вдаються до тої самої «стратегії».

Натомість історія розвитку в'язничної системи на українських землях потребує не «гучних радянських кліше», а об'єктивного фахового вивчення та виваженого підходу. Аналіз діяльності діячів тюремної реформи, що формували систему виконання покарань, стояли у її витоків, чи не найкраще ілюструє всю складність цієї системи, її багатоаспектність і потребу в фахівцях високого рівня і професійних знань, і особистих якостей.

Радикальне відмежування від історії Російської імперії, у складі якої українські землі перебували тривалий період, упродовж якого формувалася тюремна система як усієї імперії, так і українських губерній, створює штучну «білу пляму». Думається, несправедливо, що нині Російська Федерація узурпувала історичну пам'ять і надбання Російської імперії - держави, яку населяли сотні народів.

Створення 1879 р. Головного тюремного управління Російської імперії було вагомим кроком уперед на шляху формування модерної в'язничної системи в дусі загальноєвропейських пенітенціарних перетворень. I з огляду на 140-літній ювілей утворення першого центрального тюремного відомства, яке здійснювало управління й тюремною системою українських губерній, нам видається доречним розглянути основні етапи його діяльності через призму юридичної біографістики, акцентувавши увагу на персоналіях керівників Головного тюремного управління, їх життєвому та професійному шляху, а також їх внеску в справу тюремної реформи.

Постановка завдання. Мета статті - окреслити умови створення Головного тюремного управління Російської імперії; визначити його структуру, повноваження начальника управління; уточнити перелік та хронологію перебування на посадах очільників Головного тюремного управління, визначити та проаналізувати діяльність керівників центрального тюремного відомства.

Аналіз останніх досліджень і публікацій. Історіографія тюремної реформи в Російській імперії та правових засад діяльності Головного тюремного управління (ГТУ) досить значна: це і фундаментальні праці А. П. Печникова, М. Г. Дєткова, І. В. Упорова, I. І. Бомбергер та ін. Не можна оминути й вітчизняних авторів, які почасти звертали увагу на цю проблематику, зокрема I. В. Іваньков О. П. Неалов, В. В. Россіхін, О. Н. Ярмиш, М. М. Яцишин.

До 130-літнього ювілею ГТУ опубліковано низку статей під назвою «Во главе тюремного ведомства», де наведено короткі нариси про усіх очільників ГТУ, але вони мають радше довідковий характер [1]. Серед російської історіографії слід виділити монографічне дослідження саратовського історика С. В. Зубова, у якому значну увагу звернуто на реформаторську діяльність М. М. ГалкінаВраського в тюремній сфері [2]. Останнім часом опубліковано кілька біографічних досліджень про 
П.К.Грана, але його діяльність на посаді очільника ГТУ згадується фрагментарно [3; 4].

Здобутки керівників тюремного відомства подано в огляді діяльності ГТУ за перші 35 років його існування [5]. Цінним джерелом стали публікації в офіційному виданні ГТУ - журналі «Тюремний вісник», а також спеціальний випуск, що містив статті про причини трагічної загибелі О. М. Максимовського.

На особливу увагу заслуговують дослідження в царині юридичної біографістики і тюрмознавства знаного вітчизняного історика права В. М. Чиснікова [6; 7], в одному з яких розглянуто діяльність ГТУ під керівництвом генерала П. Г. Курлова.

У межах науково-дослідної роботи кафедри загально-юридичних дисциплін Інституту кримінально-виконавчої служби започатковано дослідження 3 пенітенціарної біографістики, видано збірку «Пенітенціарна наука і практика крізь призму юридичної біографістики», до якої увійшли наукові розвідки про М. М. Галкіна-Враського [8] та П. К. Грана [9]. Особливий інтерес для дослідників становить остання публікація, оскільки в ії основу лягли неопубліковані спогади П. К. Грана 3 приватного архіву. Окремо видано наукові статті про діяльність О. М. Максимовського [10] та О. О. Жижиленка [11].

Виклад основного матеріалу. Створення центрального органу управління тюремною системою цілком відповідало тим прогресивним перетворенням, що відбувалися в Російській імперії впродовж 60-70-х років XIX ст. Знаковим кроком було підпорядкування 1862 р. усіх місць позбавлення волі цивільного відом- ства MBC, що фактично стало початком реформаторського руху у сфері виконання покарань.

У результаті роботи спеціальних комісій та комітетів упродовж 1868-1877 pр. було вироблено кілька проектів тюремних перетворень. Усі вони передбачали створення центрального органу управління тюремною системою, започаткування посад головних тюремних інспекторів для контролю за діяльністю установ виконання покарань та губернського тюремного інспектора як координатора цієї діяльності в регіоні.

Започаткування 27 лютого 1879 р. в структурі МВС Головного тюремного управління стало центральним етапом тюремної реформи в Російській імперії. Головне тюремне управління було автономним i, згідно із законом, користувалося певною самостійністю. Начальник ГТУ мав право приймати рішення про застосування необхідних виконавчих і розпорядчих заходів у тюремній галузі, не питаючи на це додаткового дозволу міністра внутрішніх справ. Він призначався указом царя за поданням міністра внутрішніх справ і володів достатньо широкими повноваженнями: завідував усіма цивільними місцями ув'язнення, арештантською пересильною частиною, виправними притулками; відповідав за витрату асигнованих за кошторисом кредитів; здійснював нагляд за органами місцевого тюремного управління; керував підпорядкованою йому конвойною вартою.

У безпосередньому підпорядкуванні начальника ГТУ перебував його помічник, на якого покладались обов'язки завідування канцелярією управління та виконання обов'язків начальника в разі його відсутності 
або хвороби. Особливе місце в штаті ГТУ займали тюремні інспектори, які безпосередньо підпорядкувалися начальникові управління. Інспектори направлялись у регіони для збирання даних, що стосувалися тюремної частини й були необхідні для ознайомлення зі станом тюрем і розроблення законодавчих і адміністративних заходів щодо покращення їх устрою.

Першим очільником новоствореного центрального тюремного відомства був призначений Саратовський губернатор Михайло Миколайович Галкін-Враський.

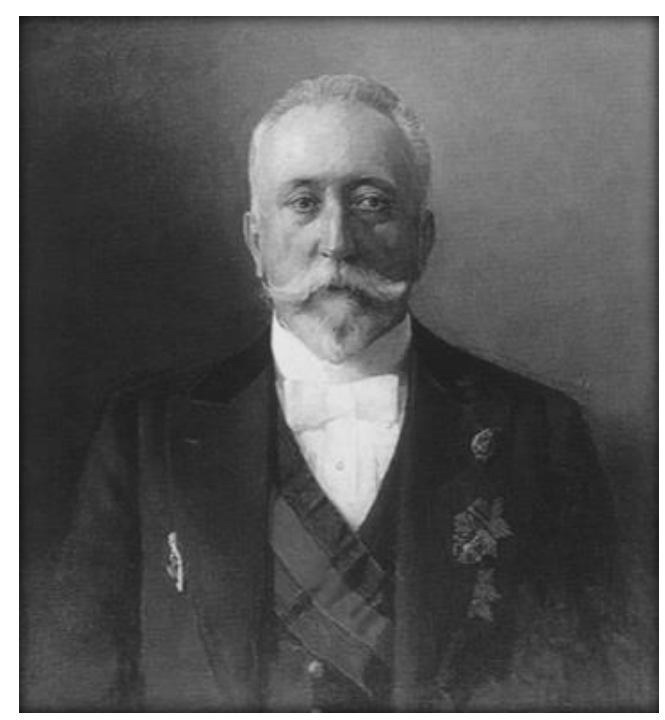

М. М. Галкін-Враський (1832-1916)

Походив він зі старовинного дворянського роду - Галкіних (по лінії батька) i Враських (з боку матері). Народився Михайло Миколайович 1832 р. у родовому маєтку Галкіних - с. Полянки Спаського повіту Казанської губернії. 1853 року закінчив юридичний факультет Казанського університету [2, с. 32-35].

У червні 1862 р. М. М. ГалкінВраський був зарахований на службу до MBC і з того часу зацікавився про- блемою організації тюремної справи в Росії і за кордоном. Перебуваючи 1862 р. в Європі, оглянув установи виконання покарань і ознайомився із засадами функціонування різних в'язничних систем. Інтерес до тюремної проблематики став вирішальним у всій його подальшій долі й кар'єрі.

1868 року він опублікував «Материалы к изучению тюремного вопроса», у яких виклав історію розвитку західноєвропейської пенітенціарної науки, схеми устрою та плани найбільших в'язниць, проаналізував основні види тюремного ув'язнення, що застосовувалися на Заході [12]. Досить довго це видання було єдиним в Російській імперії посібником 3 тюрмознавства.

Після завершення закордонного відрядження М. М. ГалкінВраський брав активну участь у роботі Санкт-Петербурзького тюремного комітету, а 1867 р. затверджений одним із семи його директорів. На цій посаді він долучився до будівництва й облаштування нової експериментальної в'язниці для строкових арештантів у Санкт-Петербурзі.

29 березня 1868 р. указом Олександра II M. М. Галкін-Враський призначений начальником Петербурзької в'язниці для строкових арештантів. Керував діяльністю цього закладу він недовго - лише півроку, але за цей час закладено засади діяльності в'язниці, запроваджено обов'язкову працю арештантів, було встановлено оплату праці засуджених (частину зароблених коштів ув'язнені отримували під час звільнення). Важливим нововведенням М. М. Галкіна-Враського була видача атестатів засудженим, які оволоділи певним ремеслом, та організація товариства, що допомагало таким особам влаштуватися 
на роботу після звільнення $[13$, с. $85-$ 86].

Також Михайло Миколайович брав участь у роботі комісії з реформування тюремної частини під головуванням графа К. Палена 1867 p. Лист М. М. Галкіна-Враського до К. К. Грота 3 приводу роботи зазначеної комісії демонструє широку обізнаність автора в питаннях організації майбутнього центрального тюремного відомства, власне бачення його функцій як самостійного управління, відокремленого від інших напрямів діяльності («оно должно быть выгорожено от соучастия других управлений Министерства»), у безпосередньому підпорядкуванні міністра. 3 огляду на необхідну його окремішність, М.М.Галкін-Враський вважав непринциповим питання, у складі якого саме міністерства має перебувати центральне тюремне управління: MBC чи міністерства юстиції [2, с. 109].

Після довгих і плідних років державної служби Естляндським, а пізніше Саратовським губернатором 1879 р. М. М. Галкіну-Враському довелося знову повернутися до проблем виконання покарань і стати першим очільником новоствореного тюремного відомства. 23 квітня 1879 р. імператор Олександр II призначив його начальником ГТУ. Цю посаду Михайло Миколайович обіймав упродовж 17 років.

3 його ініціативи імперія приєдналася до міжнародного тюремного співтовариства і стала учасником тюремних (пенітенціарних) конгресів. Він входив до складу міжнародної тюремної комісії, яка працювала між конгресами. 1885 року на III Miжнародному тюремному конгресі в Римі М. М. Галкін-Враський предста- вляв делегацію Російської імперії. А 1890 р. організував проведення IV Міжнародного тюремного конгресу в Санкт-Петербурзі, де був обраний пожиттєвим почесним головою.

Михайло Миколайович був прихильником ідеї виправлення засуджених через залучення їх до праці. Закон про обов'язковість праці ув'язнених і розподіл отриманих доходів був затверджений Олександром III 6 січня 1886 р. Він заклав нормативні основи організації праці засуджених, що приносило значні кошти державній скарбниці.

Другою важливою реформою, проведеною М. М. Галкіним-Враським, було затвердження нових штатів тюремної варти. Положення про тюремну варту від 15 червня 1887 р. внесло суттєві зміни в організацію тюремної справи: штати тюремних службовців були розширені, а їх оклади підвищені [8].

Також 1890 р. М. М. ГалкінимВраським ініційовано створення місцевих органів тюремного управління - губернської тюремної інспекції. Інспекції були представниками ГТУ в губерніях, через яких воно підтримувало зв'язок 3 окремими місцями ув'язнення. Упродовж 18901896 pp. тюремні інспекції були створені в 24 губерніях, зокрема в Катеринославській, Київській, Полтавській, Харківській, Херсонській, Чернігівській.

Оцінюючи результати функціонування ГТУ під керівництвом М. М. Галкіна-Враського з 1879 по 1896 рр., варто відзначити, що в цей період вироблено ті організаційноправові основи діяльності пенітенціарної системи, які були затребувані при всіх наступних політичних режимах. 
Одним із суперечливих напрямів реформаторської діяльності М. М. Галкіна-Враського став проект перетворення системи заслання та каторги до Сибіру та освоєння в цьому контексті о. Сахалін. Власне і завершення кар'єри очільника тюремного відомства було пов'язане з трагедією 1889 р. на Карійській каторзі, де політичні засуджені вчинили масове самогубство, протестуючи проти свавілля адміністрації каторжних тюрем. Безпосередньо Михайло Миколайович не був причетним до трагедії, але відповідальним за ту політику, що реалізовувалася стосовно політичних злочинців в місцях несвободи, стан тюрем та умови утримання, а також за діяльність тюремної адміністрації. Кінець 80-х - початок 90-х років XIX ст. позначився наступом на привілеї засуджених за політичні злочини, проти чого останні активно виступали.

Невдачею завершились і починання М. М. Галкіна-Враського щодо сільськогосподарської колонізації о. Сахалін зсильнокаторжними. Він залишався палким прихильником цієї ідеї навіть після завершення каденції на посаді очільника ГТУ і всупереч численним заявам науковців та управлінців, які наголошували на неефективності й неможливості реалізації колонізації острова таким чином [14].

13 грудня 1895 року тюремне відомство перейшло в підпорядкування міністерства юстиції, що було зумовлено продовженням тюремних перетворень, переглядом кримінальних законів та утвердженням ідеї, що сфера виконання покарань $\epsilon$ складовою кримінальної юстиції. А. П. Печников серед причин такої передачі називає також переобтяже- ність МВС різними функціями і бажання зосередити його зусилля, насамперед, на боротьбі з політичними злочинцями, а не карними, які, перебуваючи в тюрмах, загрози для самодержавства вже не становили [15, c. 136-138].

Але й були ті, хто не бачив у цьому перепідпорядкуванні «високої державницької мети». Так, відомий юрист А. Ф. Коні вважав, що в основі такого рішення були інтриги й особиста зацікавленість міністра юстиції М. В. Муравйова: «Вследствие совокупного представления министров - Горемыкина и Муравьева - состоялась, без всякого законодательного обсуждения, передача всего тюремного дела [...] в ведение министра юстиции. Скудный бюджет тюремного ведомства остался в основаниях своих прежним, личный состав тоже, но генерал-прокурор и блюститель правосудия, сделавшийся обертюремщиком и хозяйственным распорядителем по тюремной части, получил прибавку содержания и мундир тюремного ведомства с присвоенными ему золотыми жгутами и шашкою [...] Едва ли от этого тюремное дело улучшилось» [16, с. 23].

Подібної думки дотримувався і М. М. Гернет, саркастично відзначаючи, що міністерство юстиції свою діяльність щодо керівництва ГТУ почало з указу про заміну гудзиків на форменому одязі: «На этом примере видно, чем интересовалось тюремное управление прежде всего». Заради справедливості слід зазначити, що «головний історик царської тюрми» не шкодував «шпильок» на адресу ГТУ. Зокрема про М. М. Галкіна-Враського і міжнародну співпрацю писав: «первый начальник Главного тюремного управления позаботился с самого начала 
своей деятельности завязать сношения с иностранными тюремными управлениями, выразившиеся ... в обмене фотографиями с главным тюремным начальником» $[17$, с. 13-14].

Спогади генерала П. Г. Курлова теж підтверджують, що підпорядкування ГТУ міністерству юстиції, здійснене за бажанням міністра юстиції М. В. Муравйова, було цілком випадковим [18].

Фактичний перехід тюремної системи в підпорядкування міністерства юстиції відбувався поступово, що мало супроводжуватися відповідним нормативним забезпеченням. Для цього була створена комісія 3 укладання законодавчих пропозицій про устрій тюремної частини в міністерстві юстиції під головуванням сенатора М. С. Таганцева. Комісія працювала упродовж 1896 р. й виробила докладний план передачі тюремної системи від одного відомства до іншого. Головним результатом іï роботи був висновок про необхідність виділення тюремного управління зі складу губернського правління та 3-під керівництва губернатора. Цим рішенням досягалася мета відокремити MBC в особі губернатора і міністерство юстиції в особі особливої колегії, щоб вони не могли впливати одне на одного [19, с. 32]. Отже, управління тюрмами на місцях повинно було зосередитися в руках тюремних інспекцій, а не губернатора. Особливих змін в організації діяльності ГТУ не відбулося, лише начальник призначався тепер за поданням міністра юстиції.

28 лютого 1896 р. М. М. ГалкінВраський залишив посаду начальника ГТУ і 8 березня 1896 р. на це місце було призначено члена зазначеної комісії при міністерстві юстиції То- больського губернатора Миколу Модестовича Богдановича.

Закінчивши Петербурзький університет, М. М. Богданович служив у міністерстві юстиції. У 1876 р. був призначений товаришем київського губернського прокурора. 3 1878 р. по 1986 р. обіймав посади товариша прокурора Варшавського та Петербурзького окружних судів.

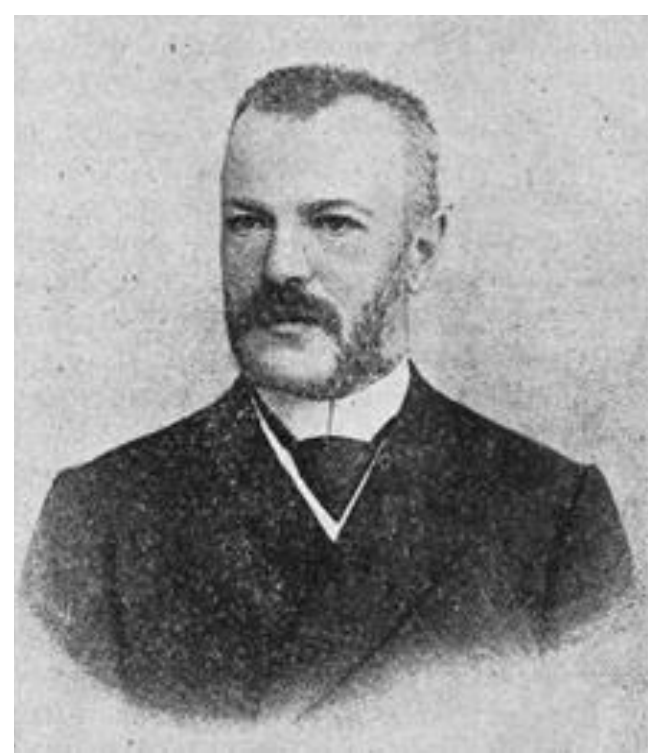

М. М. Богданович (1856-1903)

Як свідчать офіційні джерела, зі своїми обов'язками Микола Модестович справлявся успішно, кар'єра його складалася вдало. 1887 року М. М. Богданович перейшов на службу в MBC і відразу був призначений віцегубернатором у Ломжу, пізніше - віцегубернатором у Ригу, а незабаром обійняв пост Тобольського губернатора [1, с. 37].

3 огляду на службу в органах юстиції, обізнаність у тюремних питаннях та значний управлінський досвід М. М. Богданович не випадково був призначений очільником тюремного відомства. Однак уже в жовтні 
того ж року через хворобу (ослаблення слуху), що вимагала зміни клімату, був змушений залишити посаду й отримав призначення губернатором в Уфу.

Життєвий шлях М. М. Богдановича, а особливо його трагічний фінал, $\epsilon$ досить показовим для розуміння політичної ситуації та суспільного тла, в умовах якого доводилося працювати вищому державному чиновнику Російської імперії на межі XIX-XX ст. Так звана Златоустівська бійня стала фатальною в біографії М. М. Богдановича.

10 березня 1903 р. робітники м. Златоуст розпочали страйк, протестуючи проти введення нових розрахункових книжок та правил, що скасовували пільги щодо користування заводською землею та т.і. I хоча керуючий справами усіх заводів округу - гірничий начальник А. О. Зелєнцов, що, до речі, одним із перших запровадив в окрузі 8-годинний робочий день, дозволив протестувальникам тимчасово працювати без розрахункових книжок та погодився задовольнити їх окремі вимоги, підбурені екстремістами молоді робітники відмовилися виходити на роботи і перешкоджали в цьому іншим [20].

До Златоуста було викликано частини Мокшанського полку. Для перемовин 3 адміністрацією робітники обрали уповноважених, але їх заарештувала поліція. 12 березня дві тисячі робітників зібралися на площі, вимагаючи звільнити заарештованих. Поводилися вони досить зухвало, намагалися увірватися до будинку ісправника, погрожували йому розправою, стягнули з ганку офіцера, погнули штики тощо.

До страйкарів на перемовини негайно прибув губернатор М. М. Богданович, пообіцявши розібратися в ситуації. 13 березня неконтрольований натовп знову зібрався на Арсенальній площі Златоуста. Жодні обіцянки губернатора звільнити заарештованих активістів та вимоги розійтися до остаточного вирішення питання, інакше їх буде розігнано силою, не діяли. Страйкарі намагались увірватися до будинку гірничого начальника, 3 натовпу пролунали револьверні постріли. 3 огляду на це губернатор прийняв рішення збройно зупинити заворушення i командир батальйону віддав наказ стріляти в бік натовпу. У результаті цього було вбито й поранено кілька десятків осіб. 17 березня 1903 р. було оприлюднено звернення губернатора до громадськості 3 детальним поясненням причин його розпорядження застосувати зброю та переліком загиблих і поранених [21, с. 69-72].

Златоустівська бійня викликала протест робітників у всій країні, а революційно налаштовані організації оголосили М. М. Богдановича ворогом робітничого класу і винесли йому смертний вирок.

Микола Модестович не раз запитував себе, чи правильно він учинив, картав за те, що не викликав сотню козаків, які б нагайками розігнали натовп. Губернатора попереджали про небезпеку, що загрожувала йому 3 боку революціонерів-терористів, але він себе жодним чином не убезпечив. 6 травня 1903 р. 20-літній есер Є. Дулєбов підстеріг губернатора в міському парку й смертельно його поранив.

Ось що писали про ці події петербурзькі газети: «Телеграф приніс звістку про новий мерзенний злочин, жертвою якого став один з найбільш освічених і гуманних російських губернаторів - М. М. Богданович, добре знаний у Петербурзі як колишній на- 
чальник Головного тюремного управлінн»я («Новий Час», 7 травня 1903 р.) [20].

Убивства терористами-революціонерами державних діячів були в цей час в Російській імперії звичною справою. Так, двоє очільників ГТУ, М. М. Богданович та О. М. Максимовський, стали їх жертвами. Парадоксальність ситуації в тому, що суспільство не засуджувало ці дії, і нерідко присяжні виправдовували терористів. Саме в таких суспільнополітичних умовах доводилося реалізовувати свої функції службовцям тюремного відомства.

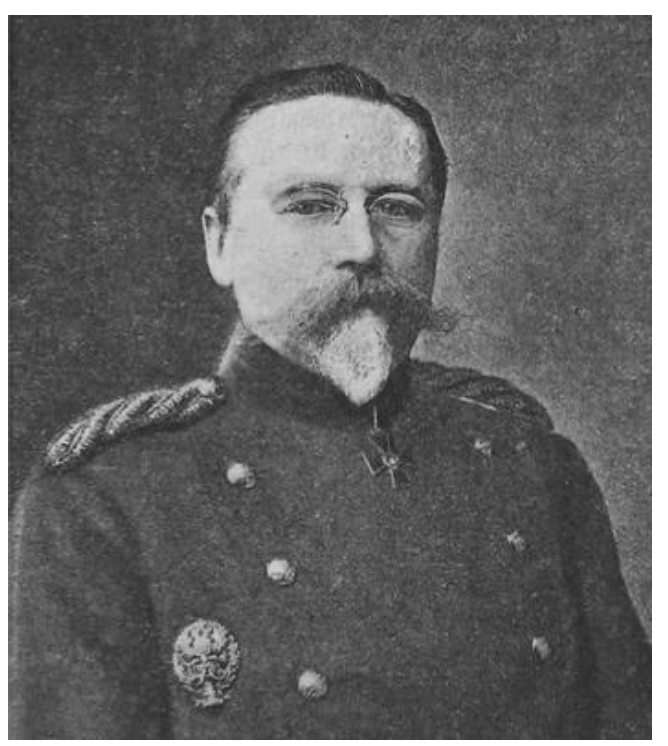

О. П. Саломон

(1855-1908)

Наступним начальником ГТУ 11 листопада 1896 р. було призначено Олександра Петровича Саломона.

О. П. Саломон народився 1855 р. Закінчивши 1874 р. із золотою медаллю Імператорський Олександрівський ліцей, О. П. Саломон вступив 1875 р. на службу рядовим у лейбгвардії Гренадерський полк. Після завершення військової кар'єри в травні 1881 р. був відряджений на цивільну службу до ГТУ. Він вивчав тюремну справу за кордоном, брав участь у проведенні в'язничної реформи. 28 листопада 1881 р. його призначено секретарем Ради 3 тюремних справ.

О. П. Саломон представляв державу на III Міжнародному тюремному конгресі в Римі, був членом комісії з організації та проведення IV Міжнародного тюремного конгресу в Санкт-Петербурзі. Упродовж 1888-1891 рр. обіймав посади інспектора ГTУ VI і V класу [22, с. 240241].

Одне 3 найбільших досягнень О. П. Саломона на посаді начальника ГТУ - робота з вивчення стану справ з відбуванням заслання та каторги в Сибіру та на о. Сахалін. У травні 1899 р. О. П. Саломон став членом, а пізніше очолив, комісію з організації заходів щодо скасування заслання. Олександр Петрович, на відміну від М. М. Галкіна-Враського, прихильно і 3 інтересом поставився до праці А. П. Чехова «Острів Сахалін», у якій критично змальовано колонізацію острова засудженими. 1898 року О. П. Саломон особисто відбув у відрядження до Сибіру та на о. Сахалін для ознайомлення 3 умовами заслання і каторги. За підсумками поїздки він представив доповідь про «несосотоятельность ссылочной системы» і необхідність їі скасування, що пізніше була опублікована окремим виданням [23]. Свої погляди щодо стану справ у тюремній системі та перспектив її розвитку О. П. Саломон виклав у праці «Тюремное дело в России» [24].

Після звільнення з посади начальника ГТУ О. П. Саломон упродовж 1900-1908 рр. служив директором Олександрівського ліцею. 


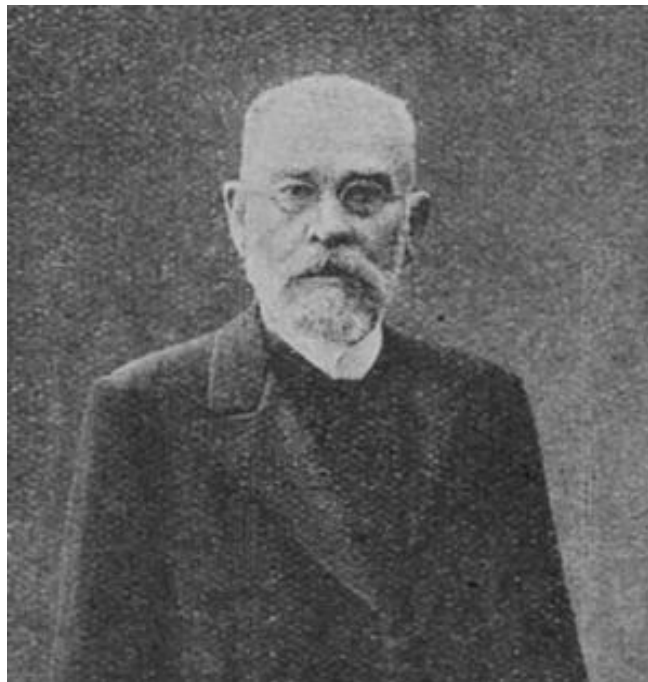

I. В. Мещанінов (1846-1918)

19 жовтня 1900 р. очільником ГТУ призначено Івана Васильовича Мещанінова, який обіймав цю посаду досить нетривалий час - до 1 квітня $1901 \mathrm{p}$.

Народився І. В. Мещанінов 17 серпня 1846 р. в Саратовській губернії у дворянській родині. 1868 року закінчив юридичний факультет Казанського імператорського університету. Працював судовим слідчим та на інших посадах у судових установах Казанської губернії. У 1884 р. переїхав до Санкт-Петербурга. 31887 р. товариш обер-прокурора кримінального касаційного департаменту Сенату. 31893 р. - член консультації міністерства юстиції з ревізійних доручень, а з 1900 р. - член Урядового Сенату [1, с. 46].

I. В. Мещанінов входив до складу комісії з організації заходів щодо скасування заслання. Іван Васильович залишив посаду очільника ГТУ внаслідок призначення його товаришем міністра народної освіти.

Авторству I. В. Мещанінова належать праці 3 тюрмознавчої тема- тики: «Из истории русской тюрьмы» [25] та «Из воспоминаний старого тюремного деятеля» [26].

Після відставки І. В. Мещанінова начальником ГТУ призначено дійсного статського радника Андрія Михайловича Стремоухова, який перебував на цій посаді 38 травня 1901 р. по 6 вересня 1905 р. Походив він зі стародавнього дворянського роду. Навчався у військовому училищі. Упродовж 1896-1901 рр. керував тимчасовою канцелярією з розгляду особливих кримінальних справ при міністерстві юстиції [1, с. 46].

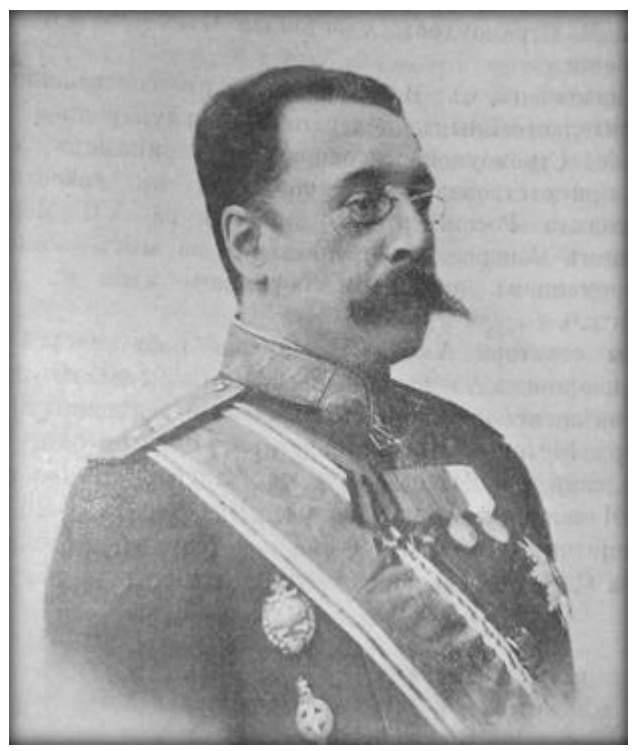

А. М. Стремоухов

(1854-1913)

Призначення Андрія Михайловича в ГТУ відбулося відразу після видання закону про скасування заслання. Це зумовило значні зміни в роботі усієї системи виконання покарань. Після ухвалення нового Кримінального уложення терміново слід було виробити проект перебудови усіх місць ув'язнення відповідно до вимог закону. А. М. Стремоухов здійснював безпосереднє керівництво цією роботою. 
3 ініціативи начальника ГТУ здійснено низку заходів 3 покращення побуту засуджених, засновано тюремну богадільню на о. Сахалін, змінено штати управління островом, створено комісію для розподілу зсильнокаторжних, бродяг тощо. Переглянуто штати московських місць ув'язнення, а також збільшено штат ГТУ. У 1905 p. завершено реформу виправних арештантських відділень й ухвалено нові штати [27].

За безпосередньої участі А. М. Стремоухова в березні 1902 р. організовано проведення першого з'їзду тюремних діячів у СанктПетербурзі.

У 1902 році у складі ГТУ утворено 7-ме діловодство (рахункове, 3 організації арештантських робіт), бухгалтерія, запроваджено посаду 2го помічника начальника. 1904 року ухвалено Основні правила харчування і лікування арештантів виправних арештантських відділень і Порядок утримання у в'язницях цивільного відомства політичних арештантів. А. М. Стремоухов особисто брав участь у розробленні закону, що скасовував найтяжчі види тілесних покарань для зсильних.

А. М. Стремоухов підготував до Міжнародного пенітенціарного конгресу у Будапешті звіт про заходи щодо тюремної частини, здійснені 3 1900 р. по 1905 р. [28].

У зв'язку з переведенням на посаду директора 2-го департаменту міністерства юстиції А. М. Стремоухов залишив пост начальника ГТУ $[1$, c. 46$]$.

25 лютого 1906 р. начальником ГТУ призначено заступника А. М. Стремоухова Олексія Михайловича Максимовського, який фактично вже вісім місяців здійснював

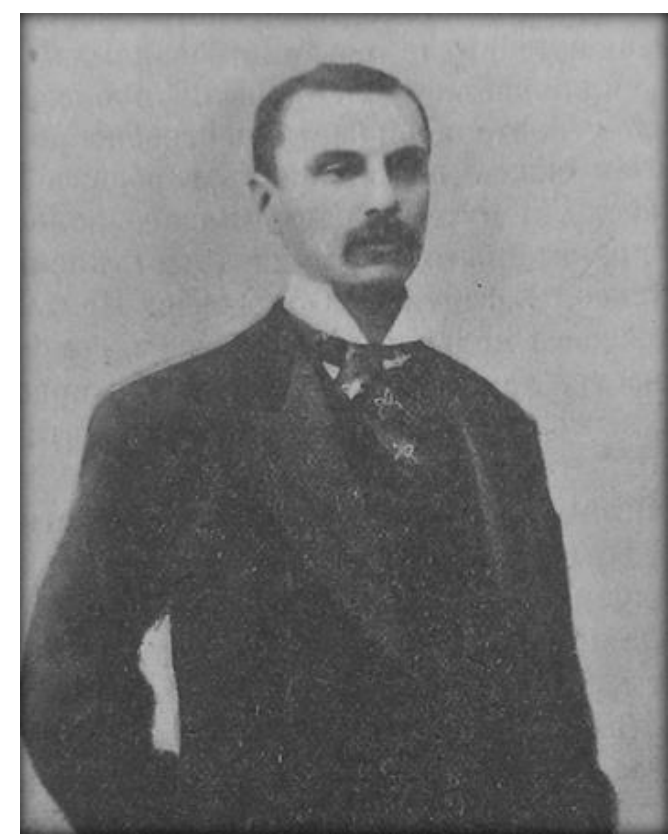

О. М. Максимовський (1861-1907)

управління тюремним відомством у період відсутності А. М. Стремоухова.

Олексія Михайловича Максимовського можна назвати одним 3 найбільш неординарних керівників тюремного відомства: уважний доброзичливий сором'язливий, до того Ж глибоко віруючий християнин, голова Товариства поширення Святого письма (Євангельського Петербурзького товариства), який усе своє життя розглядав як земне служіння Ісусові Христу [11, с. 57].

Народився Олександр Михайлович 30 серпня 1861 р. в СанктПетербурзі в дворянській родині генерала М. С. Максимовського. 1883 року, після завершення навчання на юридичному факультеті Харківського університету, вступив на службу до міністерства народної просвіти. 3 1885 р. упродовж кількох років служив у Державній канцелярії, з 1894 р. - обіймав посаду помічника статссекретаря Державної Ради. 
Абсолютно не обізнаному в тюремній справі службовцю міністерства юстиції О. М. Максимовському перейти до ГТУ на новостворену посаду помічника начальника запропонував А. М. Стремоухов. 11 лютого 1902 р. він був відкомандирований до ГТУ «для занятий по законодательной части», а 18 травня призначений помічником начальника.

На цій посаді Олександр Михайлович перебував більше трьох років. Зазначені законодавчі акти, ухвалені у період з 1902 по 1905 рр., розроблено за дієвої участі 0. М. Максимовського. Крім законотворчої діяльності, Олександр Михайлович долучився до вирішення найважливіших питань управління тюремним відомством, неодноразово проводив ревізії місць позбавлення волі тощо.

Варто акцентувати увагу, що діяльність О. М. Максимовського у тюремному відомстві припала на важкі революційні роки соціальних зрушень 1905-1907 рр. Здавалося, ліві газети всю антиурядову лють виплескували на поліцію і тюремних службовців. Тюрма змальовувалася у пресі як знаряддя особистої помсти уряду революційно налаштованим масам. В умовах переповненості місць ув'язнення будь-яка спроба підтримки порядку викликала спротив серед громадськості, підбуреної антиурядовими публікаціями. Преса формувала образ тюремника як ката, ворога свободи й сатрапа. Це не лише підривало авторитет тюремних службовців серед засуджених, заставляло боятися за свою безпеку (дедалі частішими ставали вбивства та замахи на життя тюремників), але й було ударом по і так непрестижній тюремній службі [29, с. 679].
Видання ж правого спрямування, навпаки, звинувачували тюремне відомство в потуранні політичним засудженим, надто «ліберальному» режимі, встановленні на засадах «гуманності» в тюрмах «раю для всіх шахраїв, грабіжників й убивць». Отже тюремне відомство, як правильно зазначалося, перебувало між молотом і ковадлом $[29$, с. $679-$ 680].

У такій політичні ситуації ГТУ дедалі частіше доводилося нагадувати начальникам тюрем, що основним керівним началом їх діяльності повинні бути приписи закону і засновані на них розпорядження. О. М. Макимовський відстоював думку, що тюрма передусім повинна бути тюрмою - надійним місцем позбавлення волі, і встановлений порядок, режим та дисципліна повинні визнаватися неминучими в будь-якій добре влаштованій тюремній установі [29, с. 681]. «Ми не кати, - підкреслював 0. М. Максимовський, - ми лише утримуємо в ув'язненні тих, кому призначив покарання суд» [30].

Основним завданням тюремної адміністрації в умовах політичної нестабільності, переповненості тюрем та їх незадовільного стану було забезпечення порядку та відповідного режиму утримання, упровадження, за можливості, ідей виправлення засуджених і налагодження виробництва.

Завдяки О. М. Максимовському в один будівельний сезон 1907 p. вдалося облаштувати нові в'язниці в Москві, Миколаєві, Шліссельбурзі $[29$, с. 681]. Особливу увагу Олександр Михайлович приділяв розвитку арештантської праці, що розглядалася ним одночасно і як засіб мо- 
рального перевиховання злочинця, i як спосіб установлення належного режиму в тюрмі, порядку й дисципліни серед арештантів. У період його керівництва тюремним відомством започатковано використання засуджених на меліоративних роботах для розширення селянських земельних угідь і на виробництві обмундирування та взуття для військових потреб.

О. М. Максимовський чітко уявляв програму діяльності ГТУ та необхідні перетворення. Першочерговими заходами вважав удосконалення місцевого тюремного управління 3 метою покращення службового i матеріального становища тюремної адміністрації та варти. Крім того, необхідно було впорядкувати тюремно-будівельну частину, збільшити кошторис на спорудження і ремонт тюрем. Важливе місце в його програмі займали питання реорганізації каторги, перегляд приписів, що регулювали діяльність виправних притулків, тощо.

Не все задумане О. М. Максимовським реалізовано за час перебування на посаді начальника ГТУ. Але, в умовах постійного браку коштів, зроблено досить багато:

- вдалося досягти деякого збільшення виділення коштів на тюремно-будівельні роботи і збільшення на 520000 руб. щорічного кошторису на утримання особового складу наглядачів;

- підготовлено проект Положення про виправно-виховні заклади для неповнолітніх;

- розроблено і подано на затвердження проект реформування місцевого тюремного управління, який був однією з основних складових модернізації всієї тюремної сис- теми імперії та передбачав виокремлення з відання губернатора тюремних справ і підпорядкування їх виключно тюремним інспекціям, підконтрольним ГТУ, які були би наділені значною самостійністю в питаннях управління місцями позбавлення волі та арештанськопересильною частиною. Товариству ж піклувальному про тюрми відводилася роль виключно благодійна;

- розпочато роботу з організації централізованої спеціальної професійної підготовки і навчання тюремних службовців;

- впроваджено зарубіжний досвід дактилоскопії засуджених і створено при ГТУ Центральне дактилоскопічне бюро [6, с. 214].

Чіткий, принциповий i професійний підхід О. М. Максимовського до своїх обов'язків поєднувався 3 його надзвичайно уважним ставленням до потреб підлеглих та скарг засуджених. Завжди доброзичливий до людей, здатний знаходити в кожному хороші якості, Олександр Михайлович щиро вірив, що правильно організований тюремний режим, праця і заходи духовно-морального впливу не можуть не навернути навіть самого запеклого злочинця на чесний шлях. О. М. Максимовському найбільш близька була ідея виправлення злочинця шляхом надання йому можливості самому, через працю, духовне зростання, гарну поведінку, покращити своє становище [29, c. 683].

Жодним чином не сумніваючись у людських якостях Олександра Михайловича і не применшуючи його здобутки на посаді очільника ГТУ, все ж, заради справедливості, наведемо характеристику, яку дав йому як управлінцю один із його підлег- 
лих, тюремний інспектор П.К. Гран, який пізніше очолив центральне тюремне відомство: О.М. Максимовський відрізнявся рідкісною працьовитістю і чуйністю, але зовсім не підходив на роль керівника тюремного відомства. Хворобливо вразливий $i$ мало обізнаний з адміністративною справою, він був знаряддям в руках своїх найбільш спритних і досвідчених підлеглих. Вони нерідко змушували свого керівника виносити рішення, що не відповідали його переконанням, $i$ нести весь тягар наслідків таких рішень. Будучи гуманною людиною, О. М. Максимовський як керівник ГТУ підписував досить суворі циркуляри, що стосувалися порядку утримання засуджених й інколи, цілком справедливо, накладав стягнення на тюремних службовців. Зробивши те чи інше рішуче розпорядження, він відразу ж шкодував про це, звинувачуючи себе в необачності або жорстокості $i$, відчуваючи глибокі моральні страждання, впадав в повну прострацію. Попри це, О.М. Максимовський не вважав себе в праві відмовитися від хреста, що випав на його долю, хоча тягар цей для нього був нестерпним ... доки куля фанатично налаштованої Рагозиннікової не поклала край його стражданням [31, с. 32-33].

В умовах наростаючої ненависті в суспільстві до тюремників загалом і очільника тюремного відомства зокрема, на яких преса покладала всю відповідальність за долю революціонерів у «царських застінках», O. М. Максимовський став жертвою теракту, підготовленого бойовиками-есерами.

15 жовтня 1907 р. до будівлі ГТУ зайшла молода дівчина й попросила провести її до начальника тюремного управління. Через кілька

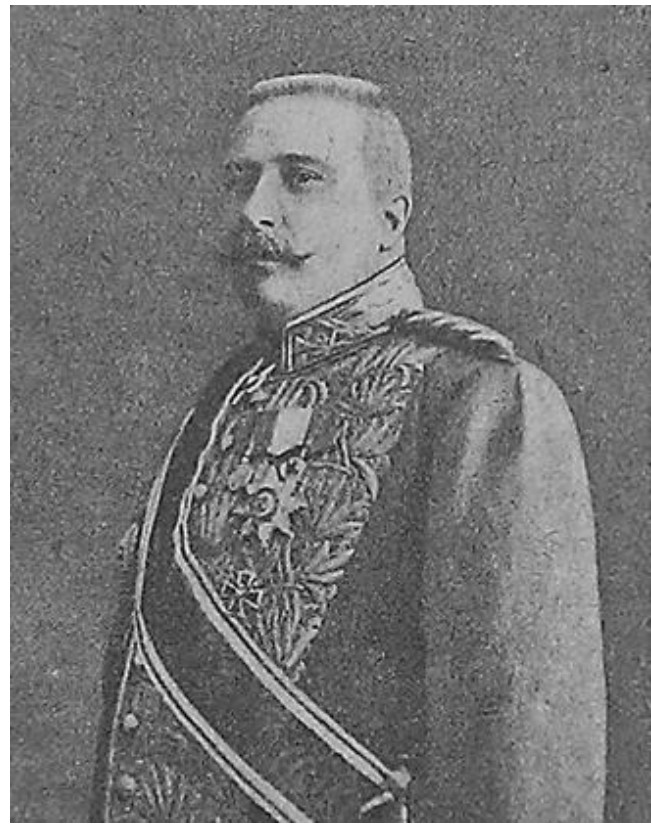

П. Г. Курлов

(1860-1923)

годин, коли в приймальні з'явився Олександр Михайлович, візитерка, зробивши крок на зустріч, упритул вистрілила в нього. О. М. Максимовський помер у лікарні, не приходячи до тями [32, с. 675]. Вбивцею виявилася $Є$. Рагозиннікова, член північного бойового летючого загону партії есерів.

31 жовтня 1907 р. засновано фонд імені О. М. Максимовського для надання допомоги незаможним сім'ям тюремних службовців, які постраждали від тифу чи терористичних актів.

26 жовтня 1907 р. начальником ГТУ, замість убитого О. М. Максимовського, призначено Павла Григоровича Курлова - досвідченого управлінця, відомого на той час державного діяча. Зі слів сучасників і колег, генерал Курлов був, безумовно, людиною обдарованою i, звичайно, досить освіченою, юрист, у минулому прокурор i губернатор, він був 
визнаним фахівцем у питаннях внутрішнього управління [7, с. 325].

П. Г. Курлов народився 05 січня 1860 р. у дворянській родині поміщиків-землевласників Курської губернії. Після навчання у Миколаївському кавалерійському училищі служив у Кінно-гренадерському полку, а потім у Таурогенській, Бакинській та С.-Петербурзькій бригадах прикордонної варти. 1888 року Павло Григорович закінчив Олександрівську військово-юридичну академію та був відряджений до військової прокуратури Московського окружного суду, обіймав посади товариша прокурора Костромського та Тверського окружних судів. Упродовж 1892-1900 рр. перебував на посадах товариша прокурора Володимирського, Вологодського, Московського окружних судів та Московської судової палати.

1903 року П. Г. Курлов перейшов на службу до МВС та отримав посаду Курського віце-губернатора, з 1905 до 1906 р. - Мінський губернатор.

07 жовтня 1906 р. П. Г. Курлова призначено членом Ради міністерства внутрішніх справ. 3 грудня 1906 р. по лютий 1907 р. він тимчасово виконував обов'язки Київського губернатора. 3 квітня 1907 р. - виконуючий обов'язки віце-директора (пізніше - директора) Департаменту поліції МВС, завідувач Особливого відділу. Наприкінці жовтня 1907 року П. Г. Курлов очолив ГТУ.

Про своє несподіване призначення на цю посаду Павло Григорович писав: «Я был весьма удивлен, когда на другой день после убийства Максимовского меня неожиданно вызвали к министру, который просил меня принять должность начальника главного тюремного управления [...] На мое замечание, что министр юс- тиции И.Г.Щегловитов, в ведении которого находилось главное тюремное управление, не особенно ко мне благоволил и, конечно, имеет в виду заместить этот пост каким-либо излюбленным своим человеком из чинов судебного ведомства, П. А. Столыпин ответил, что он уже переговорил с министром юстиции, который сам предложил мне это назначение и готов принять условия, мной поставленные. Успокоив меня, что мой уход из ведомства министерства внутренних дел есть только временная командировка, министр просил меня поехать к И. Г. Щегловитову. Последний принял меня без замедления, встретил, с внешней стороны, необычайно дружелюбно и, не дав мне сказать о цели моего приезда, в самых лестных для меня выражениях предложил занять пост начальника главного тюремного управления» [18].

Вступаючи на посаду, П. Г. Курлов досить чітко висловив власне бачення підвладного йому відомства, що, на його думку, повинно бути незалежним від міністерства юстиції; кошторист ГТУ теж повинен бути відокремлений від бюджету міністерства [18].

Ознайомившись зі станом справ у ГТУ, П. Г. Курлов відзначив, що воно перевантажене роботою, яку не могло «розвантажити» навіть збільшення штату. Після ознайомлення з особовим складом управління Павло Григорович відзначив, що кількісна недостатність чиновників з лишкою покривається їх якістю, і відверто визнавав, що за всю свою довголітню службу такого прекрасного 3 усіх поглядів підбору службовців, як у ГТУ, він не зустрічав [7, с. 322].

3 ініціативи П. Г. Курлова в ГТУ утворено 8-й відділ - законодавчий. 
За період його керівництва та подекуди за безпосередньою участю розроблено низку законопроектів, зокрема про заміну каторжних робіт до Сибіру, скасування заслання до Сибіру на «вічні часи», надання службовцям тюремного відомства, які постраждали під час виконання службових обов'язків, і членам їх сімей пільг.

3 огляду на незадовільний стан справ в установах виконання покарань щодо умов утримання засуджених, основні зусилля очільника ГТУ були спрямовані на збільшення державних асигнувань на 1909 р. на потреби тюремного відомства.

П. Г. Курлов як представник уряду входив до складу міжнародної пенітенціарної комісії. Значну увагу начальника ГТУ було звернуто на виправно-виховні заклади для неповнолітніх [1, с. 47], організацію арештантських робіт, навчання засуджених ремеслам [7, с. 324].

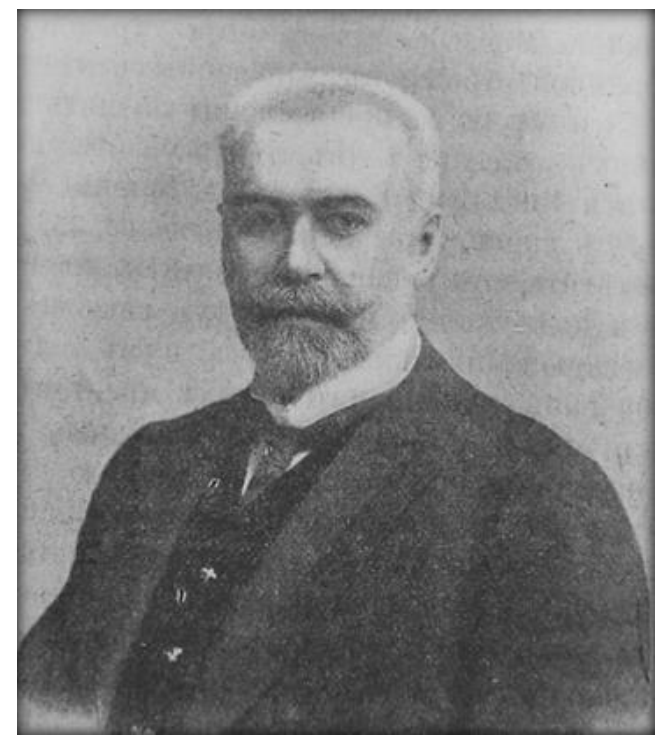

С. С. Хрульов

(1860-1913)

01 січня 1909 р. П. Г. Курлова призначили товаришем міністра внутрішніх справ, а з 24 березня - ще й командиром Окремого корпусу жандармів.

На посаду ж начальника ГТУ 12 січня 1909 р. призначено знаного юриста 3 багаторічним досвідом прокурорської діяльності - Степана Степановича Хрульова.

Народився С. С. Хрульов 2 липня 1860 р. у дворянській родині в СанктПетербурзі. 1884 року закінчив юридичний факультет Санкт-Петербурзького університету. Службову кар'єру розпочав кандидатом на посаду при прокуророві СанктПетербурзької судової палати. 31889 по 1894 рр. обіймав посади товариша прокурора Володимирського, Московського та Санкт-Петербурзького окружних судів. У 1894 р. С. С. Хрульова призначено прокурором Ярославського окружного суду, пізніше - Нижньогородського окружного суду, з 1900 р. - товаришем прокурор Санкт-Петербурзької судової палати. 31903 р. С. С. Хрульов прокурор Харківської судової палати. У жовтні 1907 р. призначений на посаду прокурора Московської судової палати.

У Харкові прокурор судової палати С. С. Хрульов разом з виконуючим обов'язки товариша прокурора B. I. Сокальським підтримували обвинувачення в гучному судовому процесі про зловживання в Харківському земельному і торгових банках [33].

Степан Степанович активно поєднував роботу з науковою та громадською діяльністю - очолював різноманітні спілки, був автором статей, у яких звертав особливу увагу на належну організацію виховного процесу серед неповнолітніх злочинців.

У Ярославлі С. С. Хрульов ініціював організацію товариства допомоги особам, що звільняються 3 місць позбавлення волі, та був обра- 
ний його головою. У Нижньому Новгороді клопотав про створення в місті товариства допомоги неповнолітнім, які звільнялися 3 місцевої виправної колонії. Нерідко виступав благодійником, фондуючи кошти на допомогу неповнолітнім-засудженим. За сприяння С. С. Хрульова в Харкові створено губернську спілку допомоги особам, звільненим з місць позбавлення волі.

Після призначення начальником ГТУ С. С. Хрульов відразу відбув у відрядження до Сибіру з метою вивчення ситуації в місцях відбування покарання у виді каторги.

С. С. Хрульов - один із авторів Положення про виправно-виховні установи для неповнолітніх 1909 р. та закону «Про умовно-дострокове звільнення» 1909 р. [1, с. 34].

Упродовж 1910-1911 рр. значні зрушення відбулися в питанні будівництва мережі нових тюрем, зокрема для довгострокового утримання, та виділення коштів на це. ГТУ ініційовано складання опису всіх існуючих місць ув'язнення і розроблення плану спорудження нових і реконструкції діючих тюрем. Відповідно до законів 1910 р. та 1912 р. утворено тюремні інспекції в більш ніж 20 губерніях [5, с. 330-333].

С. С. Хрульов долучився до роботи в міжнародній комісії з підготовки пенітенціарних конгресів, у процесі якої оглянув пенітенціарні установи Франції, Бельгії, Німеччини. Узяв участь у VIII Міжнародному пенітенціарному конгресі, до якого підготував звіт про діяльність ГТУ за 1905-1910 pp.

1912 року реорганізовано структуру ГТУ та збільшено штат до 56 класних чинів та 41 канцеляриста [15, c. 141].
Значним кроком на шляху нормативного забезпечення організації діяльності тюремних установ було видання 1912 р. Загальної тюремної інструкції та Пам'ятки тюремного наглядача.

Також вдалося втілити ідею професійної підготовки тюремного персоналу. Головним тюремним управлінням 1912 р. розроблено законопроект про організацію й діяльність Вищих тюремних курсів. 3 ініціативи С. С. Хрульова 1913 р. започатковано відкриті читання, програма яких розроблялася у відповідно до нового проекту Загальної тюремної інструкції [34, с. 1203-1209].

Діяльність С. С. Хрульова високо оцінена владою. На ювілейній виставці 1911 р. ГТУ присуджено нагороду «за розвиток внутрішніх та зовнішніх арештантських робіт та правильну їх організацію», а С. С. Хрульов отримав чин дійсного статського радника.

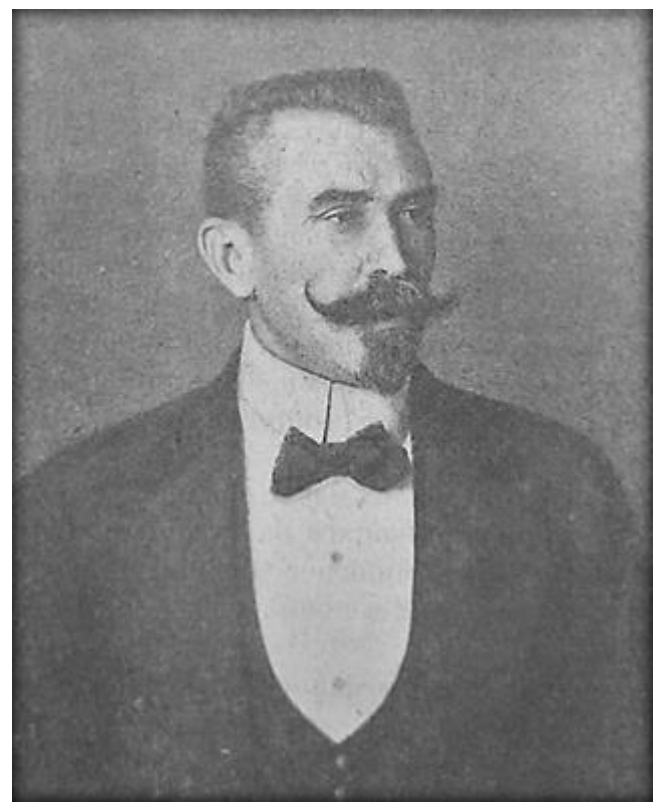

П. К. Гран (1869-1941) 
Помер С. С. Хрульов 28 березня 1913 р., перебуваючи на посаді.

Наступним начальником ГТУ в квітні 1913 р. було призначено Iркутського губернатора, колишнього тюремного інспектора Петра Карловича Грана. Міністр юстиції І. Г. Щегловітов, коли П. К. Гран прибув до нього в кабінет, з радістю зауважив: «Наконец-то, я Вас получил» [9, c. 28].

Народився П. К. Гран 19 листопада 1869 р. в маєтку Дубровка Саратовської губернії в сім'ї К. К. Грана, нащадка французів-гугенотів. Мати Ольга Михайлівна походила з запорізького роду Маленко-Байкових.

Після закінчення Імператорського училища правознавства П. К. Гран розпочав кар'єру зі служби в Департаменті урядового Сенату. Навесні 1893 р. він переїхав у Твер, де отримав посаду молодшого чиновника з особливих доручень при губернаторі. Завдяки старанній праці Петро Карлович швидко заслужив довіру губернатора й переїхав до Новгорода, а згодом - до Ярославля.

Восени 1900 р. П. К. Гран перейшов на службу в Міністерство народної освіти і обійняв посаду управляючого канцелярією Ризького учбового округу. Але прослужив там лише рік і був призначеним Ярославським губернським тюремним інспектором. Відвідуючи розташовані в Ярославлі та повітах місця ув'язнення, він намагався ознайомитися 3 їх внутрішнім розпорядком, вивчити психологію арештантів. Для цього він постійно інспектував тюрми i, по можливості, частіше залишався наодинці із засудженими. У результаті, П. К. Гран зробив висновок, що більшість засуджених стали жертвами обставин і повної незахищено- сті перед спокусами життя. Приблизно 90\% з них вчинили свій перший злочин по «п'яній» чи «жіночій» справі [9, с. 25].

На посаді тюремного інспектора П. К. Гран особливу увагу приділяв питанням організації праці в'язнів 3 метою, з одного боку, відволікти їх від буденності, а з іншої - зацікавити заробітком. Через три роки оплачуваною виробничою працею вдалось зайняти до $80 \%$ всіх ув'язнених. В Ярославській губернії була відкрита єдина в імперії суконно-ткацька фабрика у місцях позбавлення волі.

П. К. Гран вважав, що в основі відносин тюремної адміністрації та арештантів повинна бути неупередженість і повага до людської гідності. Шляхом погроз і перетворення особи на машину не можна ії виправити чи зробити корисною для суспільства. Повернути засудженого до соціуму нарівні 3 іншими громадянами - ось мета, яку ставив перед собою П. К. Гран на посаді тюремного інспектора.

Діяльність Ярославського тюремного інспектора не залишилася непоміченою в Санкт-Петербурзі. Помічник начальника ГТУ О. М. Максимовський зацікавився організацією тюремної справи в Ярославлі й особисто 3 нею ознайомився. Після призначення О. М. Максимовського начальником ГТУ П. К. Грану навесні 1906 р. запропоновано проінспектувати сибірські каторжні тюрми. Після цієї ревізії П. К. Грана переведено з Ярославля до Петербурга на посаду інспектора V класу ГТУ.

Служба в ГТУ скоро стала для нього тягарем. Міністр внутрішніх справ П. А. Столипін підтримав прагнення П. К. Грана повернутися до адміністративної діяльності й 1907 р. 
призначив його керуючим канцелярією Іркутського генерал-губернатора. А 1908 р. - Іркутським губернатором.

04 травня 1913 р. П. К. Гран очолив ГТУ. Його діяльність на цій посаді співпала з активною роботою Державної Думи. Йому часто доводилося стикатися з нетерпимістю депутатів до представників уряду, псевдодемократичністю й демагогією, особливо серед представників лівих партій. Через партійні суперечки та конфронтацію з урядом законопроекти часто роками «блукали» 3 одної комісії в іншу. Наприклад, представлена восени 1913 р. міністром юстиції реформа каторги пролежала в канцелярії Думи до Лютневої революції 1917 р. [9, с. 28].

Навесні 1914 р. для роботи в комісії з розроблення програми Міжнародного пенітенціарного конгресу, запланованого на 1915 р., П. К. Гран отримав закордонне відрядження, під час якого ознайомився 3 організацією тюремної справи в Англії, Hiмеччині та Франції.

За час перебування П. К. Грана на посаді голови тюремного відомства під його управлінням знаходилось більше 700 місць позбавлення волі і до 4000 сільськогосподарських ферм, цегельних заводів та інших виробництв. Він організував у складі ГТУ нові діловодства: 10-те (з тюремній охорони і режиму), 11-те (пенсійне), 12-те (штатне і нагородне), 13-те (по постачанню працівників тюремного відомства обмундируванням і спорядженням), 14-те (для нагляду за санітарними умовами в'язнів), 15-те (по найму приміщень), а також будівельний комітет. У 1916 р. при ГТУ відкрито завод 3 виготовлення артилерійських снарядів.
У період керівництва П. К. Граном підготовлено й затверджено Табелі речового забезпечення (22 лютого 1914 р.), Новий опис форменого одягу й озброєння тюремних наглядачів і наглядачок (28 лютого 1914 р.), Інструкція для спостережних комісій за місцями ув'язнення міста Санкт-Петербурга (27 січня 1917 р.), остаточно була затверджена й набрала чинності Загальна тюремна інструкція 1915 p.

Після Лютневої революції 1917 р. П. К. Гран подав у відставку. У своїх спогадах він писав: «Мне был чужд «новый порядок» - на улицах, вместо рослых городовых, суетились юноши с красными повязками, изображавшие милищию, всюду замечалось постепенное проникающие господство толпы и ничем не стесняемого хамства» $[9$, с. 30].

Після переїзду 1917 р. у Томськ, пізніше в Іркутськ, П. К. Гран певний час співпрацював із Сибірським урядом, упродовж 1919 р. очолював Головне управління місцями ув'язнення Російського уряду О. В. Колчака [4].

7 березня 1917 р. за пропозицією міністра юстиції О. Ф. Керенського Тимчасовий уряд призначив начальником ГТУ професора Олександра Олександровича Жижиленка. Важко $з$ упевненістю сказати, чим було зумовлено це призначення, але 3 огляду на тезу, що в своїй кадровій політиці О. Ф. Керенський дотримувався принципу призначати на всі вищі посади більш менш популярних осіб за умови, що їх пов'язувала спільна діяльність чи громадські й політичні організації, воно не було випадковим. О. О. Жижиленко належав до партії кадетів і був знаним спеціалістом у теорії покарань. 


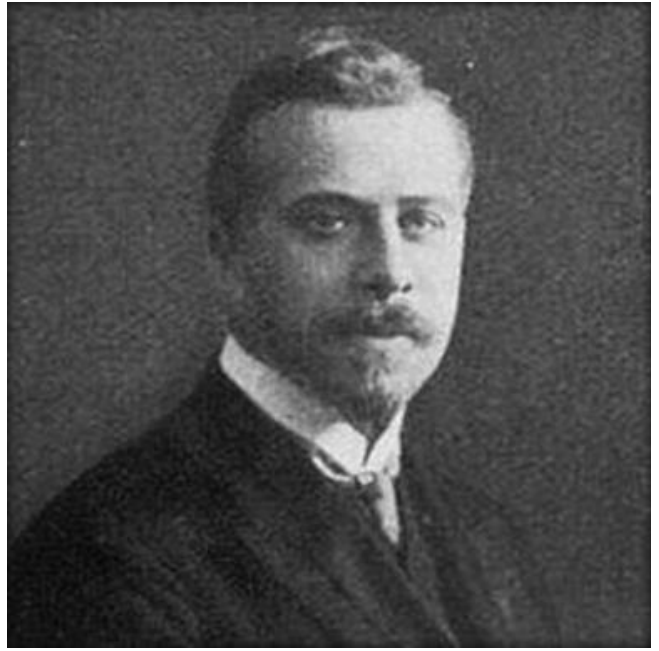

О. О. Жижиленко

(1873-1930)

Народився О. О. Жижиленко 15 жовтня 1873 p. у Боровичах Новгородської губернії в сім'ї чиновника. 1891 року він закінчив Калішську гімназію та вступив на юридичний факультет Санкт-Петербурзького університету. Після завершення навчання йому було запропоновано залишитися в університеті для підготовки до професорського звання. 1900 року захистив магістерську дисертацію на тему «Фальсифікація документів. Історикодогматичне дослідження» і був обраний екстраординарним професором кримінального права Петербурзького університету.

1915 року О. О. Жижиленко захистив у Харківському університеті докторську дисертацію «Покарання. Його поняття і відмінність від інших правоохоронних засобів». Після чого зайняв посаду ординарного професора Петроградського університету. Учений брав активну участь у роботі Юридичного товариства при університеті, був членом комітету Російської групи Міжнародного союзу криміналістів [10, с. 92-93].
Очолити тюремне відомство молодому професору О. О. Жижиленку, який не мав досвіду адміністративної роботи, довелося в надзвичайно складний час. Тюремна система в перші дні Лютневої революції постраждала чи не найбільше. В умовах хаосу й анархії Тимчасовому уряду довелося спішно розробляти засади нової кримінальної політики. У результаті квітневої амністії «тюремне населення» скоротилося на 4/5. Станом на 1 березня 1917 р. в імперії утримувалося близько 158 тис. осіб, у липні 1917 р. - 25 тис., у вересні - 36 тис. $[35$, c. 86$]$.

Зберігши загалом імперську систему, тюремне управління на чолі 3 0. О. Жижиленком розпочало розроблення нової доктрини кримінальновиконавчої політики. Зміна засад діяльності тюремного відомства була зумовлена як кримінальною політикою Тимчасового уряду, ключовим моментом якої стала амністія, так і загальними ліберально-демократичними перетвореннями.

Головне тюремне управління 26 квітня 1917 р. було перейменовано в Головне управління місць ув'язнення (ГУМУ). Постановою від 27 липня 1917 р. реорганізовано його структуру. До складу ГУМУ входили канцелярія, пенітенціарний (основний), фінансовий, господарський та законодавчий відділи [35, с. 92].

В одному з перших розпоряджень О. О. Жижиленка зазначалося, що головне завдання покарання перевиховання людини, для його належного здійснення передусім необхідно проявити гуманність до ув'язнених і повагу до їх особистої гідності [10, с. 93]. Відповідно до цього відбулося послаблення режиму утримання: заборонено застосовувати суворі 
заходи дисциплінарного впливу, скасовано всі видів кайданків та одягнення «гамівної сорочки», надано можливість залишати камери незамкненими, короткочасний вихід у місто тощо. На зміну поняттям «арештант» і «тюрма» прийшли «засуджений» і «місця ув'язнення» [36, с. 11].

3 ініціативи 0. О. Жижиленка, який вважав підбір і підготовку нових кадрів однією з основних складових перетворень у пенітенціарній системі, при ГУМУ було організовано тримісячні пенітенціарні курси.

Ліберальна політика Тимчасового уряду, загальні псевдодемократичні, в багато в чому популістські наміри щодо організації діяльності адміністрації місць ув'язнення й режиму утримання засуджених призвели фактично до краху системи виконання покарань. Щодо кадрової політики, то нехтування професіоналами тюремної справи та ставка на революційно свідомих працівників, які, однак, не мали досвіду роботи в такому специфічному відомстві, стали причиною того, що ГУМУ й тюремна адміністрація втратили контроль над процесом відбування покарань, а часто і над тюрмами загалом [36, c. 22-23].

Після жовтневого перевороту ГУМУ перестало існувати, а О. О. Жижиленко повернувся до викладацької діяльності.

Висновки. Створення Головного тюремного управління стало основною складовою тюремних реформ у Російській імперії в останній третині XIX ст. Підпорядковане спочатку MBC, а 31895 р. - міністерству юстиції, воно зберігало певну самостійність, що, зокрема, відобразилося й у доволі широких повноваженнях начальника Головного тюремного управління.
Особистості, які обіймали цю посаду послідовно з 1879 р. по 1917 р., а це переважно фахові юристи зі значним управлінським досвідом на посадах губернаторів або прокурорів окружних судів та судових палат, дають можливість усвідомити всю важливість людського чинника в здійсненні управління тюремним відомством в конкретних історикополітичних реаліях. Їх діяльність - це не лише демонстрація вдалого чи не дуже управління тюремною системою. Це і вміння бути, як сьогодні кажуть, «політичною фігурою», реалізовувати кримінально-виконавчу політику в умовах транзитивних змін, політичного популізму та псевдо демократизму, постійних нападів з боку преси та громадськості, проводити реформи в ситуації катастрофічного недофінансування.

Слід зауважити, що за 38 років існування ГТУ тюремна система Російської імперії, що до того була радше надбанням середньовіччя, перетворилася на одну з пенітенціарних систем Європи та світу, про що свідчить: активна участь представників ГТУ в міжнародних тюремних конгресах, вивчення та запозичення зарубіжного досвіду, упровадження системи одиночних тюрем, тюрмознавчі дослідження як науковців, так і практиків, широкий спектр публікацій на шпальтах «Тюремного вісника», і власне реформи, що їх реалізовувало тюремне відомство.

Очевидно, що ми успадкували не лише тюремні замки часів Російської імперії, але й проблеми, які були актуальними для в'язничної системи та її очільників, і залишаються таким і нині: це - і брак коштів, і потреба будівництва нових сучасних в'язничних комплексів, і непрестижність і 
низька оплата тюремної служби, негативне ставлення до неї в суспільстві. Навіть закиди преси, громадських активістів та журналістська риторика упродовж більше ніж 100 років майже не змінилися.

Сучасні тюремні реформатори часто запитують, чому вітчизняну в'язничну систему, при формальному виконанні більшості європейських стандартів, так і не вдається наблизити до зарубіжних зразків? Дозволимо собі припустити, що це було б можливим за умови еволюційного розвитку, як це відбувалося у Франції, Англї̈, Швеції, Данії та інших країнах, тієї в'язничної системи, що сформувалася в Російській імперії. Однак цьому завадили революційні зміни, які відбулися після 1917 р. Яку ж систему позбавлення волі побудували ті революціонери, що були вкрай невдоволені царською тюрмою, всім відомо.

\section{Список використаних джерел}

1. Яковлева О. Во главе тюремного ведомства. Преступление и наказание. 2009. № 1. С. 36-37; № 2. С. 46-47; № 3. С. 34-35.

2. Зубов С. В. Михаил Николаевич Галкин-Враской. Государственная и общественная деятельность. 3-е изд., испр, доп. Саратов : Издательство «КУБиК», 2017. 320 с.

3. Звягин С. П., Шергалин Е.Э. Начальник Главного управления мест заключения Министерства юстиции Российской империи и Российского правительства П. К. Гран: попытка реконструкции родословной. Сибирская ссылка. 2017. Выпуск 8(20). С. 498-504.

4. Звягин С.П. Начальник Главного управления мест заключения Министерства юстиции Российского правительства в 1919 г. П. К. Гран. Уголовноисполнительная система сегодня: взаимодействие науки и практики : межрегион. научно-практ. конф. Ч. 1. 29-30 ноября 2007 г. Новокузнецк, 2007. С. 189-190.

5. Лучинский Н.Ф. Краткий очерк деятельности Главного Тюремного Управления за первые XXXV лет его существования (1879-1914 г.г.). Тюремный вестник. 1914. № 2. С. 284-442.

6. Чисников В.Н. Малоизвестные страницы биографии Н. Ф. Лучинского известного тюрьмоведа и криминалиста Российской империи. Криміналістичний вісник. 2014. № 2 (22). С. 211-218.

7. Чисніков В.М. Головне тюремне управління Російської імперії під керівництвом генерала П. Г. Курлова (жовтень 1907 р. - грудень 1908 р.). Наука $i$ правоохорона. 2018. № 1(39). С. 320-327.

8. Зубов С.В. Главное тюремное управление Российской империи под руководством М. Н. Галкина-Враского. Пенітенціарна наука і практика крізь призму юридичної біографістики : матеріали круглого столу (Київ, 07 квітня 2014 року) / відп. ред.: І. М. Копотун, С. Г. Стеценко, О. В. Сокальська, Т. П. Ткач. Київ, 2014. С. 12-22.

9. Чайковський А.С. История одной личности: Петр Карлович Гран. Пенітенціарна наука і практика крізь призму юридичної біографістики : матеріали круглого столу (Київ, 07 квітня 2014 року) / відп. ред. : І. М. Копотун, С. Г.Стеценко, О. В. Сокальська, Т. П. Ткач. Київ, 2014. С. 23-29.

10. Сокальська О.В. Діяльність О.О.Жижиленка на посту начальника Головного управління місць ув'язнення. Науковий вісник Інституту кримінальновиконавчої служби. 2015. № 2. С. 90-98.

11. Пивовар I. В. Історичний досвід організаційно-правових перетворень у пенітенціарній системі XIX століття у період службової діяльності О. М. Максимовського. Журнал східноєвропейського права. 2016. № 25. С. 55-64. 
12. Галкин М. Н. Материалы к изучению тюремного вопроса. С.-Петербург : Типография II отделения собственной Е. В. Канцелярии, 1868. 189 с.

13. Зубов С.В. Пенитенциарная деятельность М. Н. Галкина-Враского до учреждения Главного Тюремного Управления. Перспективные направления научных исследований по истории уголовно-исполнительной системы России : материалы II Всероссийской научно-практической конференции (г. Москва, 27 марта 2019 г.) Москва, 2019. С. 84-88.

14. Див. детальніше: Чехов А. П. Остров Сахалин (Из путевых заметок). Москва : Изд. ред. журнала «Русская мысль», 1895. 520 с.

15. Печников А. П. Главное тюремное управление Российского государства, 1879 - октябрь 1917 гг. : дис. ... д-ра юрид. наук. Москва, 2002. 415 с.

16. Кони А. Ф. Статьи о государственных деятелях. Москва : Директ-Медиа, 2014. 36 c.

17. Гернет М. Н. История царской тюрьмы. В 5 т. Том 3. 1870-1900. Москва : Юридическая литература, 1961. 430 с.

18. Курлов П. Г. Гибель Императорской России. Москва : Современник, 1992. / По изданию : Курлов П. Г. Гибель Императорской России : Берлин, 1923. URL: http://militera.lib.ru/memo/russian/kurlov_pg/02.html (дата звернення: 11.02.2019).

19. Печников А. П. Главное тюремное управление российского государства, 1879 - октябрь 1917 гг. : автореферат диссертации на соискание ученой степени доктора юридических наук ; Академия управления МВД России. Москва, 2002. 52 с.

20. Печальний вальс. Уфа. Ежемесячный столичный журнал. 2005. № 7-8 (45); № 9(46) URL: http://www.journal-ufa.ru (дата звернення: 16.03.2019).

21. Галанов В. Расстрел Златоустовских рабочих 26 марта 1903 года. Былое Урала. 1924. № 3. С. 60-118.

22. Головнин П.А. Дворянский род Саломон в истории России. Электронная библиотека Музея антропологии и этнографии им. Петра Великого (Кунсткамера) PAH. 2012. URL: http://www.kunstkamera.ru/files/lib/978-5-88431-208-1/978-5-88431208-1_16.pdf (дата звернення: 11.02.2019).

23. Саломон А.П. Ссылка в Сибирь : очерк ее истории и современного положения. Санкт-Петербург : Типография С.-Петербургской тюрьмы, 1900. 339 с.

24. Саломон А.П. Тюремное дело в России. Санкт-Петербург : ГТУ, 1898. 38 с.

25. Мещанинов И. В. Из истории русской тюрьмы. Санкт-Петербург : Типография С.-Петербургской тюрьмы. 1903. 22 с.

26. Мещанинов И. В. Из воспоминаний старого тюремного деятеля. Тюремный вестник. 1908. № 10. С. 698-710.

27. Андрей Михайлович Стремоухов. Некролог. Тюремный вестник. 1914. № 1. C. $110-113$.

28. Стремоухов А. М. Краткий очерк мероприятий в области тюремного дела в России в период с 1900 по 1905 год. С.-Петербург : Типография С.-Петербургской тюрьмы. 1905. 26 с.

29. Мельник К. А. М. Максимовский и его деятельностьпо управлению тюремным ведомством. Тюремный вестник. 1907. № 9. С. 678-695.

30. Нехамкин С. Баптист-тюремщик и та, что его убила. Полуудавшийся супертеракт Евстолии Рогозинниковой. Аргументы недели. 8 ноябр. 2012. № 43 (335) URL: https://argumenti.ru/history/n364/212582 (дата звернення: 21.03.2019).

31. Рукопис спогадів П. К. Грана з приватного архіву.

32. Александр Михайлович Максимовский. Тюремный вестник. 1907. № 9. C. 661-677.

(C) Сокальська О. В., 2019 
33. Див. детальніше: Снегирев Л.Ф. Процесс о злоупотреблениях в Харьковских земельном и торговом банках. Москва, 1903. 117 с.

34. Опыт систематических чтений по тюрмоведению при Главном Тюремном Управлении. Тюремный вестник. 1912. № 6-7. С. 1203-1209.

35. Детков М.Г. Тюрьмы, лагеря и колонии России. Москва : «Вердикт-ІМ», 1999. 448 c.

36. Сокальська О. В. Тюремна система доби української національної революції (до 100-літнього ювілею). Вісник Пенітенціарної асоціації України. 2018. № 3(5). С. 726. DOI: https://doi.org/10.34015/2523-4552.2018.3.01.

\section{References}

1. Yakovleva, O. (2009). Vo glave tyuremnogo vedomstva. Prestuplenie i nakazanie, 1, 36-37; 2, 46-47; 3, 34-35 [in Russian].

2. Zubov, S. V. (2017). Mihail Nikolaevich Galkin-Vraskoy. Gosudarstvennaya i obschestvennaya deyatelnost. 3-e izd., ispr, dop. Saratov : Izdatelstvo «KUBiK» [in Russian].

3. Zvyagin, S. P., Shergalin, E. E. (2017). Nachalnik Glavnogo upravleniya mest zaklyucheniya Ministerstv yustitsii Rossiyskoy imperii i Rossiyskogo pravitelstva P. K. Gran: popyitka rekonstruktsii rodoslovnoy. Sibirskaya ssyilka, 8 (20), 498-504 [in Russian].

4. Zvyagin, S. P. (2007). Nachalnik Glavnogo upravleniya mest zaklyucheniya Ministerstva yustitsii Rossiyskogo pravitelstva v 1919 g. P. K. Gran. Ugolovno-ispolnitelnaya sistema segodnya: vzaimodeystvie nauki i praktiki : mezhregion. nauchno-prakt. konf. Ch. 1. 29-30 noyabrya 2007 g. Novokuznetsk [in Russian].

5. Luchinskiy, N. F. (1914). Kratkiy ocherk deyatelnosti Glavnogo Tyuremnogo Upravleniya za pervyie XXXV let ego suschestvovaniya (1879-1914 g.g.). Tyuremnyiy vestnik, 2, 284-442 [in Russian].

6. Chisnikov, V. N. (2014). Maloizvestnyie stranitsyi biografii N. F. Luchinskogo izvestnogo tyurmoveda i kriminalista rossiyskoy imperii. Kriminalistichniy visnik, 2 (22), 211-218 [in Russian].

7. Chisnikov, V. M. (2018). Golovne tyuremne upravlinnya Rosiyskoyi Imperiyi pid kerivnitstvom generala P. G. Kurlova (zhovten 1907 r. - gruden 1908 r.). Nauka i pravoohorona, 1(39), 320-327 [in Ukrainian].

8. Zubov, S. V. (2014). Glavnoe tyuremnoe upravlenie Rossiyskoy imperii pod rukovodstvom M. N. Galkina-Vraskogo. PenitentsIarna nauka i praktika kriz prizmu yuridichnoyi biografistiki : materiali kruglogo stolu (Kiyiv, 07 kvitnya 2014 roku) / vidp. red.: I. M. Kopotun, S. G. Stetsenko, O. V. Sokalska, T. P. Tkach. Kiyiv [in Russian].

9. Chaykovskiy, A. S. (2014). Istoriya odnoy lichnosti: Petr Karlovich Gran. PenitentsIarna nauka i praktika kriz prizmu yuridichnoyi biografistiki : materiali kruglogo stolu (Kiyiv, 07 kvitnya 2014 roku) / vidp. red.: I. M. Kopotun, S. G. Stetsenko, O. V. Sokalska, T. P. Tkach. Kiyiv [in Russian].

10. Sokalska, O. V. (2015). Diyalnist 0. O. Zhizhilenka na postu nachalnika golovnogo upravlinnya mists uv'yaznennya. Naukoviy visnik Institutu kriminalno-vikonavchoyi sluzhbi, 2, 90-98 [in Ukrainian].

11. Pivovar, I. V. (2016). Istorichniy dosvid organizatsiyno-pravovih peretvoren u penitentsiarniy sistemi XIX stolittya u period sluzhbovoyi diyalnosti O. M. Maksimovskogo. Zhurnal shidnoevropeyskogo prava, 25, 55-64 [in Ukrainian].

12. Galkin, M. N. (1868). Materialyi $k$ izucheniyu tyuremnogo voprosa. S.-Peterburg : Tipografiya II otdeleniya sobstvennoy E V. Kantselyarii [in Russian].

13. Zubov, S. V. (2019). Penitentsiarnaya deyatelnost M. N. Galkina-Vraskogo do uchrezhdeniya Glavnogo Tyuremnogo Upravleniya. Perspektivnyie napravleniya nauchnyih 
issledovaniy po istorii ugolovnoispolnitelnoy sistemyi Rossii : materialyi II Vserossiyskoy nauchnoprakticheskoy konferentsii (g. Moskva, 27 marta 2019 g.) Moskva [in Russian].

14. Div. detalnIshe: Chehov, A. P. (1895). Ostrov Sahalin (Iz putevyih zametok). Moskva : Izd. red. zhurnala «Russkaya myisl» [in Russian].

15. Pechnikov, A. P. (2002). Glavnoe tyuremnoe upravlenie Rossiyskogo gosudarstva, 1879 - oktyabr 1917 gg. (Dis. d-ra yurid. nauk). Moskva [in Russian]. Russian].

16. Koni, A. F. (2014). Stati o gosudarstvennyih deyatelyah. Moskva : Direkt-Media [in

17. Gernet, M. N. (1961). Istoriya tsarskoy tyurmyi. V 5 t. Tom 3. 1870-1900. Moskva : Yuridicheskaya literatura [in Russian].

18. Kurlov, P. G. (1992). Gibel Imperatorskoy Rossii. Moskva : Sovremennik, 1992. / Po izdaniyu: Kurlov, P. G. Gibel Imperatorskoy Rossi : Berlin, 1923. URL: http://militera.lib.ru/ memo/russian/kurlov_pg/02.html (data zvernennya: 11.02.2019) [in Russian].

19. Pechnikov, A. P. (2002). Glavnoe tyuremnoe upravlenie rossiyskogo gosudarstva, 1879 - oktyabr 1917 gg. (Avtoreferat dissertatsii na soiskanie uchenoy stepeni doktora yuridicheskih nauk). Akademiya upravleniya MVD Rossii. Moskva [in Russian].

20. Pechalniy vals. (2005). Ufa. Ezhemesyachnyiy stolichnyiy zhurnal, 7-8 (45); 9 (46)

URL: http://www.journal-ufa.ru (data zvernennya: 16.03.2019) [in Russian].

21. Galanov, V. (1924). Rasstrel Zlatoustovskih rabochih 26 marta 1903 goda. Byiloe Urala, 3, 60-118 [in Russian].

22. Golovnin, P. A. (2012). Dvoryanskiy rod Salomon v istorii Rossii. Elektronnaya biblioteka Muzeya antropologii i etnografii im. Petra Velikogo (Kunstkamera) RAN. URL: http://www.kunstkamera.ru/files/lib/978-5-88431-208-1/978-5-88431-208-1_16.pdf (data zvernennya: 11.02.2019) [in Russian].

23. Salomon, A. P. (1900). Ssyilka v Sibir : ocherk ee istorii i sovremennogo polozheniya. Sankt-Peterburg : Tipografiya S.-Peterburgskoy tyurmyi [in Russian].

24. Salomon, A. P. (1898). Tyuremnoe delo v Rossii. Sankt-Peterburg : GTU [in Russian]

25. Meschaninov, I. V. (1903). Iz istorii russkoy tyurmyi. Sankt-Peterburg : Tipografiya S.-Peterburgskoy tyurmyi [in Russian].

26. Meschaninov, I. V. (1908). Iz vospominaniy starogo tyuremnogo deyatelya. Tyuremnyiy vestnik, 10, 698-710 [in Russian].

27. Andrey Mihaylovich Stremouhov. Nekrolog. (1914). Tyuremnyiy vestnik, 1, 110113 [in Russian].

28. Stremouhov, A. M. (1905). Kratkiy ocherk meropriyatiy v oblasti tyuremnogo dela $v$ Rossii v period s 1900 po 1905 god. S.-Peterburg : Tipografiya S.-Peterburgskoy tyurmyi [in Russian].

29. Melnik, K. (1907). A. M. Maksimovskiy i ego deyatelnostpo upravleniyu tyuremnyim vedomstvom. Tyuremnyiy vestnik, 9, 678-695 [in Russian].

30. Nehamkin, S. (2012, noyabr 8). Baptist-tyuremschik i ta, chto ego ubila. Poluudavshiysya superterakt Evstolii Rogozinnikovoy. Argumentyi nedeli. URL: https://argumenti.ru/history/n364/212582 (data zvernennya: 21.03.2019) [in Russian].

31. Rukopis spogadiv P. K. Grana z privatnogo arhivu [in Russian]

32. Aleksandr Mihaylovich Maksimovskiy. (1907). Tyuremnyiy vestnik, 9, 661-677.

33. Div. detalnishe: Snegirev, L. F. (1903). Protsess o zloupotrebleniyah v Harkovskih zemelnom i torgovom bankah. Moskva [in Russian].

34. Opyit sistematicheskih chteniy po tyurmovedeniyu pri Glavnom Tyuremnom Upravlenii. (1912). Tyuremnyiy vestnik, 6-7, 1203-1209 [in Russian]. Russian].

35. Detkov, M. G. (1999). Tyurmyi, lagerya i kolonii Rossii. Moskva : «Verdikt-IM» [in 
36. Sokalska, O. V. (2018). Prison system during the Ukrainian national revolution (to the 100th anniversary). Bulletin of the Penitentiary Association of Ukraine, 3, 7-26. DOI: https://doi.org/10.34015/2523-4552.2018.3.01. [in Ukrainian].

O. Sokalska, PhD in Law, Associate Professor, Senior Researcher of the ScientificResearch Centre on Activities of the Bodies and Establishments of the State CriminalExecutive Service of Ukraine and Probation of Institute of Criminal-Executive Service e-mail: co2001@ukr.net; ORCID ID: 0000-0001-8737-0829

\section{The General prison department of the Russian Empire in the portraits of its chiefs (to its 140th anniversary)}

The article considers the preconditions, stages and consequences of the prison reform in the Russian Empire. The legal and organizational principles of the General Prison Department's activities, its administrative structure (initially in the Ministry of Internal Affairs and since 1895 in the Ministry of Justice) are determined.

The activities of the General Prison Department during 1879-1917 are considered through the life prism of the chiefs of the Prison Department: M. GalkinVraskoy, M. Bogdanovych, A. Salomon, I. Meschaninov, A. Stremoukhov, A. Maksymovskyi, P. Kurlov, S. Hrulev, P. Gran and A. Zhyzhylenko. From the standpoint of the legal biography science, their origin, education, specialty, administrative and managerial experience, the period of occupying the post of the Chief of the General Prison Department, were determined. The General Prison Department had a significant autonomy within the above mentioned ministries. Its Chief had the right to make the decision to take necessary executive and administrative measures at the prisons without asking for the permission from the Minister of Internal Affairs. The Chief was appointed by the Senate of the Government after the tsar of the Russian Empire had signed the relevant Decree at the request of the Minister of the Internal Affairs. He had rather considerable authority and significant powers.

The author of the article determines the main achievements and gaps in the activities of the chiefs of the General Prison Department of the Russian Empire during 1879-1917. It is believed that the history of the prison system of the Russian Empire is the cultural heritage of all those peoples, which lived in the Empire. It should not be usurped only by the Russian Federation, as it has already happened.

Keywords: General Prison Department of the Russian Empire; M. GalkinVraskoy; A. Stremoukhov; A. Maksymovskyi; S. Hrulev, P. Gran; A. Zhyzhylenko.

Надійшла до редакції 21.04.2019 